\title{
PROPERTIES OF AUSTEMPERED DUCTILE IRON
}

\author{
Sudhanshu Detwal ${ }^{1 *}$, Deivanathan $\mathrm{R}^{2}$ \\ ${ }^{1} M$. Tech. (CAD/CAM), SMBS, VIT University-Chennai Campus, Chennai \\ 600127, India \\ ${ }^{2}$ Associate Professor, SMBS, VIT University-Chennai Campus, Chennai \\ 600127, India
}

Received 28.12.2015

Accepted 04.03.2016

\begin{abstract}
This work concerns microstructural and mechanical properties of an austempered ductile cast iron (ADI). The ductile iron material was produced by the sand mould casting technique. Afterwards, austempering heat treatment was applied to the specimens at two different temperatures of $250^{\circ} \mathrm{C}$ and $350^{\circ} \mathrm{C}$. Austempered Ductile Irons (ADIs) were produced successfully by different two-stage heat treatments, to obtain favorable microstructure and hardness. The microstructure and hardness obtained by such variable heat treatments were compared. The austempering temperature and time were found to be decisive parameters in obtaining a desired ADI microstructure.

Key words: austempering, ADI, microstructure
\end{abstract}

\section{Introduction}

Austempered ductile iron (ADI) is considered as a new kind of engineering material and shows good combinations of high strength, ductility, toughness, fatigue strength and wear resistance. Considerable research have been conducted on microstructure and mechanical performance of austempered ductile iron[1,2]. The attractive properties of ADI are due to its unique microstructure which consists of high carbon austenite and bainitic ferrite with graphite nodules dispersed in the matrix. Nowadays, it has been used to manufacture many equipments, tools and components such as gears and crankshafts. ADI was first developed for heavy load gear wheels in Finland in 1973[3]. With the development of ADI, standards for ADI have also been published. In ASTM standard $897 \mathrm{M}-06$, there are 6 grades of ADI according to the ultimate tensile strength $[4,12]$. However, researches on ADIs are related primarily to the austempering process parameters, viz., austempering time and temperature, rather than to the standard ADI strength grade, which can be confusing to the designer of ADI

*Corresponding author: Sudhanshu Detwal, deivanathan.r@vit.ac.in 
structures [5-7]. Thus, microstructure and properties of ADI with different strength grades should be studied in detail to supply useful information for the ADI makers and component designers.

In this study, four ADIs samples were prepared; the microstructure was analysed, and hardness tests were conducted and correlated with austempering parameters.

\section{Experimental work}

\section{Materials}

The composition of the ductile iron ( $\mathrm{S}$ G iron) used in this study is shown in Table 1. The ductile iron was cast in solid cylindrical shape by sand casting technique. The dimensions of the ductile iron specimen used in our experiments are as shown in Fig.1.

Table 1. Composition of examined SG iron specimen

\begin{tabular}{|c|c|c|c|c|c|c|c|c|c|}
\hline Element & $\mathrm{C}$ & $\mathrm{Si}$ & $\mathrm{Mn}$ & $\mathrm{P}$ & $\mathrm{S}$ & $\mathrm{Cr}$ & $\mathrm{Mo}$ & $\mathrm{Ni}$ & $\mathrm{Fe}$ \\
\hline Wt.\% & 3.86 & 3.04 & 0.73 & 0.03 & 0.05 & 0.02 & $<0.02$ & $<0.06$ & \\
\hline
\end{tabular}

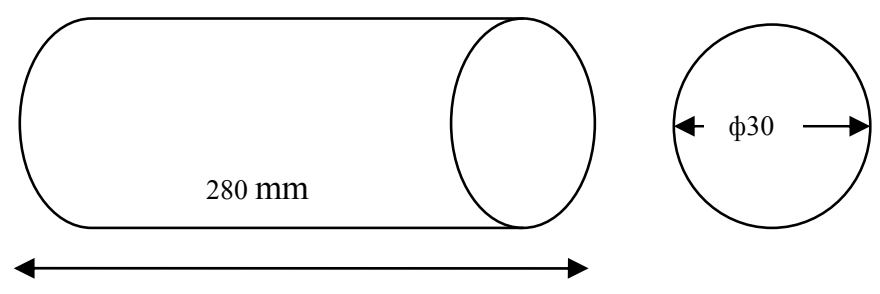

Fig. 1. Dimensions of ADI specimen

\section{Methodology}

The production of ADI in general, is constituted by a two stage heat treatment cycle. In the first stage of heat treatment, the specimen is heated in a furnace up to a little above the austenitizing temperature (i.e) $980^{\circ} \mathrm{C}$ and soaked at that point for $120 \mathrm{~min}$., to ensure that the entire cross section of the specimen has uniform microstructure. Austenitization is followed by the second stage, (i.e) austempering, which consists of rapidly transferring the specimen from the furnace into a salt bath wherein isothermal transformation of austenite occurs over a period of time specified by the soaking time. Subsequently the specimen is allowed to cool down to room temperature, and this rate of cooling is not a significant issue for cast irons.

The two stage heat treatment cycle followed in producing ADI has been summarized in Table 2. In this study, the austenitizing condition is the same for all specimens. But, the isothermal transformation is allowed to occur at two specific temperatures viz., $250^{\circ} \mathrm{C}$ and $350^{\circ} \mathrm{C}$, extending either upto $60 \mathrm{~min}$. or upto $120 \mathrm{~min}$. After the heat treatments, samples for microstructure observation, hardness test, were taken from the bottom of those blocks. 
The samples were etched in 4\% nital solution at room temperature after being polished, and then they were observed by an optical microscope. The graphite morphology was rated for the nodularity and nodule count in accordance with the ASTM standard A247.

Brinell hardness tests were carried out in the Brinell hardness testing machine with a load of $187.5 \mathrm{~kg}$ and $2.5 \mathrm{~mm}$ WC ball indentor. For each specimen, 5 readings were taken and averaged to represent the hardness values in BHN.

Table 2. Heat treatment plan for the production of four ADI specimen

\begin{tabular}{|l|c|c|c|c|}
\hline & \multicolumn{2}{|c|}{ Stage 1: Austenitization } & \multicolumn{2}{c|}{ Stage 2: Austempering } \\
\cline { 2 - 5 } & Temperature, ${ }^{\circ} \mathrm{C}$ & $\begin{array}{c}\text { Soaking time, } \\
\text { min }\end{array}$ & Temperature, ${ }^{\circ} \mathrm{C}$ & $\begin{array}{c}\text { Soaking time, } \\
\text { min }\end{array}$ \\
\hline Specimen 1 & 930 & 120 & 250 & 60 \\
\hline Specimen 2 & 930 & 120 & 250 & 120 \\
\hline Specimen 3 & 930 & 120 & 350 & 60 \\
\hline Specimen 4 & 930 & 120 & 350 & 120 \\
\hline
\end{tabular}

\section{Results and discussions}

\section{Microstructure}

The microstructures of the samples observed by optical microscope are shown in Fig. 2. All the austempered microstructures show a matrix consisting of a two-phase mixture of a dark etching bainitic ferrite, which is needle shaped, and the bright etching stabilized austenite with graphite nodules dispersed in it. The length of the ferrite needles was found to decrease with the increasing of austempered temperature and time. Austempering at $350^{\circ} \mathrm{C}$ is likely to produce a mixed ADI structure, due to early formation of pearlite caused by reacted austenite [8]. The microstructure of sample 1 , in Fig. 2, shows well preserved tempered nodular graphite in the matrix mostly consisting of bainite and ferrite structure, having nodularity $-40 \%$ and nodule count $-30 \%$. The microstructure of sample 2 is characterized by well-preserved tempered nodular graphite in the matrix mostly consisting of bainite and ferrite structure, having nodularity $-30 \%$ and nodule count $-25 \%$. The microstructure of sample 3 is shows well preserved tempered nodular graphite in a matrix mostly consisting of bainite and ferrite, having nodularity $-40 \%$ and nodule count $-50 \%$. The nodularity is rather low, known to be influenced by the charge quality and melting technique [9]. 

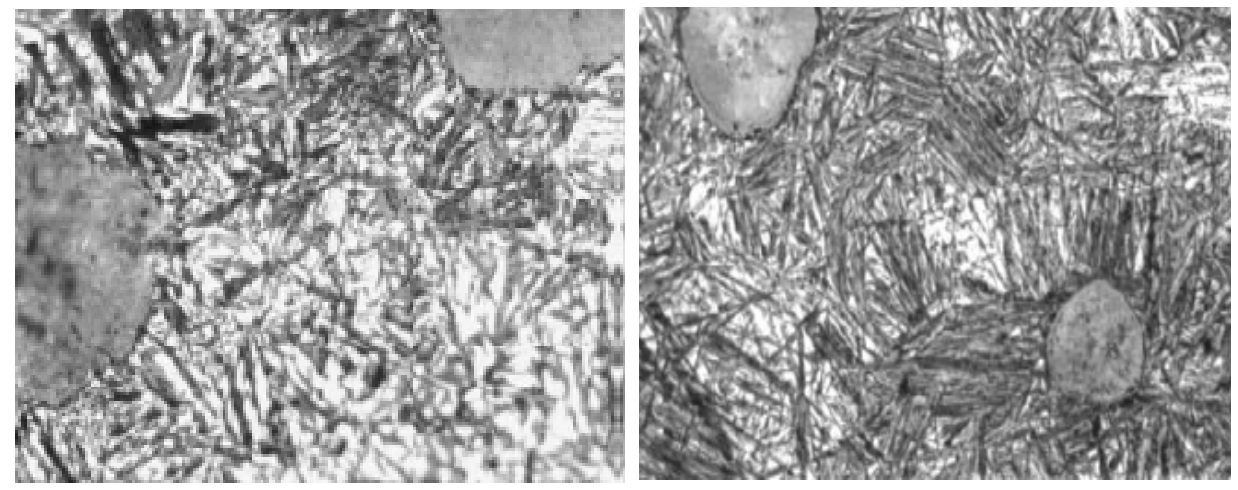

Sample $1(100 \mathrm{X})$ processed at $250^{\circ} \mathrm{C}, 1 \mathrm{hr}$

Sample 2(100X) processed at $250^{\circ} \mathrm{C}, 2 \mathrm{hr}$
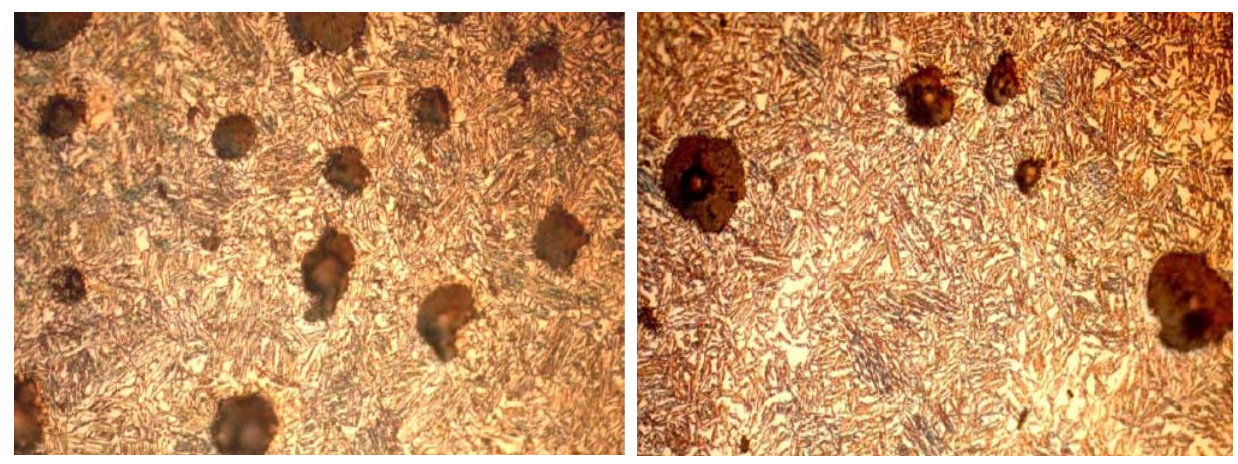

Sample $3(100 \mathrm{X})$ processed at $350^{\circ} \mathrm{C}, 1 \mathrm{hr} \quad$ Sample $4(100 \mathrm{X})$ processed at $350^{\circ} \mathrm{C}, 2 \mathrm{hr}$

Fig.2 The effect of heat treatment parameters on the microstructure of ADI

Hardness

The hardness of ADI specimen is shown in Table 3, with the corresponding austempering parameters. It can be seen that with the increase of austempered temperature the hardness of ADI decreases, however for increasing austempered time hardness increase at $250^{\circ} \mathrm{C}$ but decreases at $350^{\circ} \mathrm{C}$. Therefore, as the stabilized austenite content increases the hardness decreases. High austempering temperature prevents the formation of martensite, a hard phase, usually formed in case of low austempering temperature [10]. When the austempering temperature decreases from $350^{\circ} \mathrm{C}$ to $250^{\circ} \mathrm{C}$, the morphology of bainitic ferrite changes from upper to lower. Therefore, the austempering temperature and time are found to be decisive parameters and hence need to be optimized.

The hardness value specified by ASTM $897 \mathrm{M}-06$ for ADI Grade 750/500/11 is $241 \mathrm{BHN}$ at the minimum and is greater for higher grades [12]. The ADI specimens produced in this study, have their hardness in the range of 198-213BHN. The lower value could be related to the initial composition of the ductile iron raw material. Further, 
it is to be noted that a section size greater than $19 \mathrm{~mm}$ would require alloying additions (of $\mathrm{Cu}, \mathrm{Ni}, \mathrm{Mo}$ ) to improve the hardenability [13].

Table 3. Effect of austempering conditions on the hardness of ADI

\begin{tabular}{|c|c|c|}
\hline Specimen No. & Austempering condition & Hardness \\
\hline 1. & $250^{\circ} \mathrm{C} 1 \mathrm{hr}$ & $209 \mathrm{BHN}$ \\
\hline 2. & $250^{\circ} \mathrm{C} 2 \mathrm{hr}$ & $212 \mathrm{BHN}$ \\
\hline 3. & $350^{\circ} \mathrm{C} 1 \mathrm{hr}$ & $213 \mathrm{BHN}$ \\
\hline 4. & $350^{\circ} \mathrm{C} 2 \mathrm{hr}$ & $198 \mathrm{BHN}$ \\
\hline
\end{tabular}

\section{Conclusion}

Considering the results of this study, the following conclusions can be made:

1. The austempering temperature and time have significant influence on microstructures of ADIs. When the austempering temperature decreases from $350^{\circ} \mathrm{C}$ to $250^{\circ} \mathrm{C}$, the morphology of bainitic ferrite changes from upper to lower.

2. As the austempered temperatue decreases from $350^{\circ} \mathrm{C}$ to $250^{\circ} \mathrm{C}$, the hardness increases.

3. As the time increases for $350^{\circ} \mathrm{C}$, from 1 hour to 2 hour hardness decrease and for $250^{\circ} \mathrm{C}$, from 1 hour to 2 hour hardness increases.

4. High austempering temperature prevents the formation of martensite usually formed in low austempering temperature.

\section{References}

[1] K.B. Rundman, In: Proceedings of World Conference on Austempered Ductile Iron, Bloomingdale, IL, 1991, p1.

[2] R. Gundlach, J. Jaowak, In: Proceedings of 2nd International Conference on Austempered Ductile Iron: Your means to improved performance, productivity and cost, University of Michigan, Ann Arbor, MI, 1986, p23.

[3] Avdusinovic Hasan, Almaida Gigoric, In: Proceedings of $18^{\text {th }}$ International research conference on Trends in the development of machining and associated technologies, Budapest, Hungary, 2014, p53.

[4] GB/T 24733, Austempered ductile iron (ADI) castings, Chinese Standards (GB), 2009.

[5] G. Balachandran, A. Vadiraj, M. Kamaraj, E. Kazuya, Mater. Des. 32 (2011) 4042 4049.

[6] S.K. Putatunda, Mater. Sci. Eng., A. 315 (2001) 70-80.

[7] O. Eric, L. Sidjanin, Z. Miskovic, S. Zec, MT. Jovanovic, Mater. Lett. 58 (2004) $2707-2711$

[8] BV. Kovacs, Modern Casting, 36 (1990) 38-41.

[9] Parejiya Pavan. P, Effect of austempering behavior of ductile iron, M.Tech Thesis, Ganpat University, India, 2014.

[10] M. Kaczorowski, A. Krzynska, Arch. Foundry Eng. 7(1) (2007) 161-166.

[11] W.F. Smith, Structure and Properties of Engineering Alloys, third ed., McGrawHill, New York, 1993.

[12] Standard Specification for Austempered Ductile Iron Castings, ASTM International, 2006.

[13] K.L.Hayrynen, In: Proceedings of World Conference on ADI, Kentucky, USA, 2002. 